\title{
THE FAILURE OF SETTLEMENT OF HUMAN RIGHTS VIOLATIONS IN INDONESIA AND ITS SOLUTIONS
}

\author{
Rommy Patra \\ Faculty of Law, Tanjungpura University \\ E-mail: rommypatra@yahoo.co.id
}

\begin{abstract}
Efforts to resolve human rights violations in Indonesia have been failed. It raises the question of the cause of the failure and the solution that must be taken to overcome it. The factors causing the failure of the settlement of human rights violations: (1) weak substance of legislation, especially Law number 26 Of 2000 on the Human Rights Court; (2) issues of authority and institutional relationships that are not synergistic especially between Komnas HAM and the Attorney General; (3) weak political will from the Government. The solution offered in overcoming the failure of the completion of human rights violations: (1) improve the substantial weaknesses in Law number 26 Of 2000 on the Human Rights Court by replacing it through the establishment of a new Act on Human Rights Court; (2) to organize institutional relations between Komnas HAM and the Attorney General in order to be synergistic in handling cases of human rights violations; (3) to re-establish the Truth and Reconciliation Commission (KKR); (4) The ruling government must have strong political will to resolve various cases of human rights violations with the support of civil society groups.
\end{abstract}

Keywords: Human Rights, Human Rights Court, Komnas HAM, Violation Of Human Rights

\section{A. INTRODUCTION}

There are number of action that can be taken as an effort to resolve past human rights violations in a country that undergoing a transition era from authoritarian regimes, whether to solve it by filling it to the court (to punish); or by forgetting (to forget); or by forgiving (to pardon)? (Ifdhal Kasim dan Eddie Riyadi Terre (ed), 2003: 18). To choose from those three options is not an easy job since each option comes with its own implications and complexities and often even leads to failure in settlement of the human rights violations.

In the context of Indonesia, efforts to settle human rights violations, arguably, are met by the same dilemma in choosing between those options. The early stages of efforts to resolve human rights violations in Indonesia is the establishment of Human Rights Courts to hold accountable and punish the perpetrators, followed by the establishment of the Commission of Truth and 
Reconciliation (hereinafter refers to $K K R$ ). However, $K K R$ have not had time to work because the $K K R$ Law has been declared unconstitutional and void by the Constitutional Court Decision Number 006 / PUU-IV / 2006. With the annulment of the KKR Law, the settlement of human rights violations can only be resolved by the Human Rights Court.

Human Rights Court in Indonesia was established based on Law Number 26 Of 2000 on the Human Rights Court. Under the law, the Human Rights Court has jurisdiction to cases of gross human rights violations, namely crimes of genocide and crimes against humanity. The existence of the Human Rights Court can be divided into two types, namely the permanent Human Rights Court and the ad hoc Human Rights Court. The permanent Human Rights Court can only settle and adjudicate cases of gross human rights violations that occurred after the enactment of Law number 26 Of 2000. While the ad hoc Human Rights Court is a court established specifically to examine and settle cases of past gross human rights violations committed before the enactment of Law number 26 Of 2000.

The ad hoc Human Rights Court was established, under Article 43 of Law Number 26 Of 2000, by a Presidential Decree based on the proposal of the House of Representatives $(D P R)$. The existence of an ad hoc Human Rights Court is an exception to the non-retroactive principle, where a person can not be prosecuted by a retroactive law that is based on a law which at the time the crime was committed has not been enacted (Knut D. Asplund, et al, 2010: 307-308).

Efforts to resolve past human rights violations through the establishment of the ad hoc Human Rights Court have only been recorded in two recent cases of gross human rights violations in East Timor in 1999 and Tanjung Priok in 1984. As for the gross human rights violations that occurred after the enactment of Law Number 26 Of 2000, only Abepura case that had been prosecuted in the Human Rights Court. However, in all three cases, the Human Rights Court is considered to have failed to bring justice. (Zainal Abidin, 2012: 54-55).

The number of cases of human rights violations that have been trial in the Human Rights Court is still very little in number. Whereas many cases of human rights violations that occurred especially during the New Order regime, such as the massacre in 1965, the mysterious shootings, cases of kidnapping activists, Trisakti cases and a number of other cases, raises the question on why it can happen? It is suspected that one of the reason on why this was happened is because there were no follow-up investigation and prosecution on human rights violation cases, that have been inquiry by The National Commission on Human Rights (hereinafter refers to Komnas HAM), in the Human Rights Court by the Attorney General. This is due to the lack of synergy between institutional 
relations between Komnas HAM and the Attorney General in handling cases of human rights violations.

The implication of this has caused many cases of human rights violations that occurred in Indonesia has not been clearly settled. Indeed, this is the result of failure of the protection and enforcement system of human rights in Indonesia. The victims and their families are severely disadvantaged and suffered they are not getting justice for the human rights abuses they have suffered.

Regarding the failure of the settlement of human rights violations in Indonesia, the question arises on why the system or mechanism of protection and enforcement of human rights in Indonesia is not effective? Whereas Indonesia has a number of laws that provide human rights protection and have special institutions to handle cases of human rights violations, such as Komnas HAM and Human Rights Court. But why these institutions can not play an optimal role in the settlement of human rights violations? What is wrong with the human rights enforcement system in Indonesia so far?

\section{B. PROBLEM STATEMENT}

Based on the above issues, this paper focuses on what the factors causing the failure of the settlement of human rights violations in Indonesia and how the solutions to resolve it?

\section{ANALYSIS AND DISCUSSION}

\section{The Cause of Failure to Resolve Human Rights Violation in Indonesia}

The failure to solve cases of human rights violations in Indonesia has been due to an ineffective protection and enforcement systems caused by several factors, namely: (1) Weak substance of laws and regulations, especially Law number 26 Of 2000 on the Human Rights Court; (2) institutional design issues relating to the authority and institutional relationship among institutions particularly the ones dealing with human rights violations, such as Komnas HAM, the Attorney General and the Human Rights Court, including the lack of clarity about the stages in the formation of an ad hoc Human Rights Court; (3) lack of political will from the Government in the settlement of human rights violations. Below will disscuss the factors that lead to the failure and ineffectiveness of the settlement of human rights violations in Indonesia.

\subsection{Weakness of Law on Human Rights Court}

The ineffectiveness of the settlement of human rights violations in Indonesia is, arguably, due to the legislation that is the juridical basis in the 
settlement of human rights violations, namely Law number 26 Of 2000 on Human Rights Court which still possess a number of weaknesses. It can be summarized, at least three fundamental weaknesses of Law number 26 Of 2000: First, the substantial weakness of the Human Rights Court Law which is only a partial adaptation of the Rome Statute; Second, imperfection of the procedural law of the Human Rights Court; Third, the discrepancy of translation of the Rome Statute which affects the obscure of the substance of human rights violations which is the jurisdiction of the Human Rights Court (Halili, 2016: 200).

Below is the descriptions of details of some of the weaknesses contained in Law number 26 Of 2000 on Human Rights Court, namely (Lina Hastuti, 2012: 402-403):

First, Law number 26 Of 2000 only partially adopted the Rome Statute 1998 which underlies the establishment of International Criminal Court (ICC), whereas in the elucidation of Article 7 of Law number 26 Of 2000 that the crimes of genocide and crimes against humanity in accordance with Articles 6 and 7 of the Rome Statute 1998.

Second, Law number 26 Of 2000 does not regulate very important provisions for the implementation of an independent and impartial judicial process as stipulated in Articles 70 and 71 of the Rome Statute 1998 on offenses against the administration of justice and sanctions for misconduct before the court.

Third, Law number 26 Of 2000 also does not completely regulate international crimes that fall under the jurisdiction of the $I C C$, namely war crimes and crimes of aggression. Indonesia should be have a legal or judicial mechanisms for any violation of international humanitarian law or war crimes.

Fourth, Law Number 26 Of 2000 is not supported by procedural law within the framework of the Human Rights Court. This is in contrast to the Rome Statute of 1998 which is supplemented by special procedural law and explanations of elements of crime that fall under the ICC jurisdiction, which is in the Rules of Procedure and Element of Crime.

Fifth, the judicial process taking place in the Human Rights Court is not supported by law enforcement officers who are reliable and adequate. their understanding of the material, crime characteristics, and understanding of existing mechanisms that might be able to refer to pre-existing international court proceedings, are less visible, only few of the judges actually master.

Sixth, the number of weaknesses in Law number 26 Of 2000 on Human Rights Court are due to the fact that the formation of this Law is not purely on the basis of awareness and seriousness of the Government of Indonesia for human rights enforcement, but due to continuous pressure from the public, both nationally and internationally. As a result, Law number 26 Of 2000 is not 
prepared carefully and earnestly which should be the basis of effective national mechanism. Evidently, despite the mention of the Rome Statute of 1998, not all of the competence of the ICC jurisdiction also becomes the competence of the Human Rights Court jurisdiction based on Law Number 26 Of 2000. This is due to the absence of the Government's political will to make an effective Human Rights Court Law.

In line with the above description, based on the view of Enny Soeprapto there are also problems that lie in Law Number 26 Of 2000 relates primarily to the incomplete procedural law of the Human Rights Court, such as (Enny Soeprapto, 2011: 4):

1) the absence of a complete procedural law;

2) the absence of the subpoena power for Komnas HAM;

3) the absence of provisions on sanctions for parties who do not fulfill the call of Komnas HAM;

4) the absence of provisions on the deadline for investigators to initiate an investigation;

5) the absence of provisions governing the settlement of disagreements between investigators;

6) the absence of provisions on the procedures for proposing the establishment of an ad hoc Human Rights Court;

7) as extraordinary crimes, gross violations of human right were inquiry by special agency (Komnas HAM) and also examined by a special court (the Human Rights Court). However, investigations and prosecutions are carried out by the investigating and prosecuting agencies (Attorney General) for ordinary crimes as regulated by the Criminal Procedure Code.

\subsection{Issues of Authority and Institutional Relationship}

Failure to settle human rights violations in Indonesia is also caused by that are not synergistic institutional relations between Komnas HAM and the Attorney General regarding the relation of inquiry and investigation of gross violation of human rights. The implication of this is that Komnas HAM's inquiry into cases of human rights violations has all been halted in the Attorney General without any further investigation. Below are the numbers of cases of gross violation of human 
rights that have been inquiry by Komnas HAM but halted because it has not been followed up to the level of investigation and prosecution by the Attorney General.

\begin{tabular}{|l|l|c|}
\hline No & \multicolumn{1}{|c|}{ The name of the cases } & \multicolumn{1}{c|}{ Status } \\
\hline 1. & 27 July 1996 & Case has been halted in the Police \\
\hline 2. & Trisakti, Semanggi I \& II & Case has been halted in the Attorney General \\
\hline 3. & Case of May 1998 Riot & Case has been halted in the Attorney General \\
\hline 4. & Case Kidnapping of Activist & Case has been halted in the Attorney General \\
\hline 5. & Talangsari Lampung & Case has been halted in the Attorney General \\
\hline 6. & Wasior and Wamena & Case has been halted in the Attorney General \\
\hline
\end{tabular}

(Table 1: Cases of Gross Violation of Human Rights . Source: Komnas HAM in Ifdhal Kasim, 2011)

The number of human rights violation cases that have been inquiry by Komnas HAM but without follow-up investigation by the Attorney General is, arguably, due to the unclear pattern of relations between the two institutions in handling cases of gross human rights violations, namely (Ifdhal Kasim, 2011: 8183) :

First, the relationship between Komnas HAM and the Attorney General is related to the implementation of Law number 26 Of 2000 on Human Rights Court, which puts Komnas HAM as inquiry and Attorney General as investigator for gross human rights violation. Based on that role, Komnas HAM and the Attorney General established a relationship of subsystems, namely the relationship between inquiry and investigation in the criminal justice system (gross human rights violations). This is what distinguishes the investigation based on Law number 39 Of 1999 on Human Rights which does not place Komnas HAM directly into the criminal justice system. The role of inquiry in severe cases of gross violations of human rights is clearly not easy for Komnas HAM and this is what leads the differences of perception with the Attorney General in the context of handling cases.

Secondly, Komnas HAM in conduct inquiry of gross human rights violation has established a number of ad hoc Commission of inquiry on Human Rights Violation (KPP HAM) which investigated a number of cases that has been submitted to the Attorney General to be followed up by investigation and prosecution. In response to the Komnas HAM inquiry report, the Attorney General has the authority to assess whether the inquiry report is complete or incomplete in order to establish a suspicion of gross violation of human rights. If the conclusion 
is not complete, then the report will be returned to Komnas HAM to be completed. The Attorney General is using the formal and material require, as stipulated in the Criminal Procedural Code (KUHAP), as the basis of its assessment for the Komnas HAM inquiry report. The basis that is used by the Attorney General become a stumbling block for the institutional relations between Komnas HAM and the Attorney General.

Because in conduct to inquiry, Komnas HAM does not have to follow formal provisions as regulated in KUHAP, such as taking oaths for investigators. Especially in the inquiry of East Timor and Tanjung Priok cases, such formal requirements have never been the basis of the Attorney General's assessment. This formal requirement was only used by the Attorney General when they received the inquiry report of KPP HAM on the Trisakti, Semanggi I and II and the May 1998 Riot Incident. The Attorney General returned the inquiry reports of the cases on the basis of formal requirement. The Attorney General considered that the Komnas HAM inquiry report has not been formally completed, yet this requirement is not clearly regulated in Law number 26 Of 2000. That is one of the serious obstacles the Komnas HAM faces that often resulting in the inquiry does not continue to the investigation and prosecution phase which obstacle the cases of gross human rights violations to be brought to the Human Rights Court for trial.

Thirdly, the next issue that led to a stagnant handling of cases of gross human rights violations was the debate over the necessity of an ad hoc Human Rights Court established before investigation phase started. The Attorney General reasoned that investigators could not exercise authority such as detaining without an ad hoc Human Rights Court has established before. It was for this reason that the Attorney General returned Komnas HAM's inquiry reports. But in the investigation of gross human rights violations in the East Timor and Tanjung Priok cases, the existence of ad hoc Human Rights Court that has not yet been established did not seem to be an obstacle for the Attorney General at that time to conduct an investigation. Law Number 26 Of 2000 also does not regulate this issue clearly.

Fourth, the lack of coordination between Komnas HAM and the Attorney General, especially in the preliminary examination level has caused significant obstacles in the process of resolving gross human rights violations. Prior to the inquiry, Komnas HAM informed the Attorney General that an initial inquiry was initiated. However, at this stage the Attorney General has not initiated to inform Komnas HAM to treat the KPP HAM's report differently from the previous KPP $H A M$ 's report, especially KPP HAM Trisakti and KPP HAM for riot case of May 1998. On the other hand, Komnas HAM did not initiate to involve the Attorney 
General in the initial inquiry, for example to consult the Attorney General for an appropriate targeted inquiry on as desired by the Attorney General.

Until at present, for past human rights violations, only the Tanjung Priok and East Timor cases that have been brought to the ad hoc Human Rights Court. Meanwhile, for the cases of gross human rights violations that occurred after the enactment of Law number 26 Of 2000, only the Abepura case was brought to the Human Rights Court for trial while the status of Wasior and Wamena cases have not been clear. The reluctance of the Attorney General to investigate past human rights violation that investigated by Komnas HAM under the pretext of not yet established an ad hoc Human Rights Court is inconsistent. Since for the Wasior Incident that occurred in 2001-2002 and Wamena Incident that occurred in 2003 after the enactment of Law Number 26 Of 2000 on the Human Rights Court, the Attorney General also does not to initiate an investigation, even though the Human Rights Court already exists and was based in Makassar (Enny Soeprapto, 2011, Op.Cit: 21).

In addition to the issue of institutional relations between Komnas HAM and the Attorney General in handling gross human rights violation cases, there is also the issue of uncertainty in the stage of the establishment of an ad hoc Human Rights Court. The existence of an ad hoc Human Rights Court was established under Article 43 of Law number 26 Of 2000, namely:

(1) Gross human rights violations that occurred prior to the enactment of this Law were reviewed and decided by the ad hoc Human Rights Court.

(2) The ad hoc Human Rights Court as referred to in paragraph (1) shall be established upon the proposal of the The People's Representative Council of the Republic of Indonesia based on a particular event by a Presidential Decree.

(3) The ad hoc Human Rights Court as referred to in paragraph (1) shall be within the scope of General Courts.

Article 43 paragraph (2) of Law Number 26 Of 2000 provides the People's Representative Council (DPR) the authority to propose the establishment of an ad hoc Human Rights Court, but does not explain the stage of the establishment of the ad hoc Human Rights Court. This then led to different interpretations between the institutions associated with its formation, such as Komnas HAM, Attorney General, DPR and President. The issue is whether the ad hoc Human Rights Court is established after inquiry by Komnas HAM and the investigation by the Attorney 
General, so on the basis of the results of the inquiry and investigation, DPR proposed to the President to establish an ad hoc Human Rights Court? or is it only based on the results of inquiry by Komnas HAM, then the DPR may proposed the establishment of an ad hoc Human Rights Tribunal to the President, and only then the establishment of an ad hoc Human Rights Court may be followed up through an investigation by the Attorney General? or without waiting for the results of inquiry and investigations from Komnas HAM and the Attorney General, the DPR may decide to propose or not to propose the establishment of an ad hoc Human Rights Court. However, the question may arise on the basis of consideration on whether the DPR proposes or not to proposes to establish an ad hoc Human Rights Court when they have not obtain the inquiry and investigation result from Komnas $H A M$ and Attorney General?

Based on the Elucidation of Article 43 paragraph (2) of Law Number 26 Of 2000, DPR has the authority to determine that a certain "event" is categorized as a gross human rights violation or not. The Elucidation of Article 43 paragraph (2) of Law Number 26 Of 2000 reads as follows:

"In the case of the People's Representative Council of the Republic of Indonesia proposing the establishment of an ad hoc Human Rights Court, the The People's Representative Council of the Republic of Indonesia shall base the alleged of gross violations of human rights restricted to certain locus and tempus delicti that occurred prior to the enactment of this Law."

Question arises on what is the basis to determine that an event is a "... alleged of gross violation of human rights have occurred..." or not by DPR in order to propose the establishment of an ad hoc Human Rights Court as in the Elucidation of Article 43 paragraph (2) of Law number 26 Of 2000? Because as a political institution, the $D P R$ does not have the authority as an investigator for cases of gross human rights violations. Consequently, the consideration for the proposal of the establishment of an ad hoc Human Rights Court by the DPR is based on a political decision-making mechanism based solely on the mechanism of the $D P R$ itself which is full of compromise and negotiation of political interests. Indeed, such a mechanism is considered a blunder since a gross violation of human right case is a matter of violation of law that must be solved by law enforcement process rather than by political mechanism in the $D P R$.

The implications of the DPR's authority to propose the formation of an ad hoc Human Rights Court on the basis of "... alleged of gross violation of human rights have occurred ..." has led to differences in the results of the assessment between the DPR and Komnas HAM. Based on the results of inquiry conducted by Komnas HAM for the Trisakti case and Semanggi I and II it was concluded that there has been a gross human rights violation and therefore it need to be continued 
to the level of investigation and the establishment of an ad hoc Human Rights Court. However, according to the assessment of the DPR for Trisakti case and Semanggi I and II there are no gross violation of human rights, consequently, it is not necessary to establish an ad hoc Human Rights Court. As a result of the different assessments between Komnas HAM and the DPR until now, Trisakti case and Semanggi I and II have never brought to the ad hoc Human Rights Court and there is no clear resolution.

In fact, the issue related to the interpretation of the authority of the DPR to determine "... alleged of gross violation of human rights have occurred..." based on the Elucidation of Article 43 paragraph (2) of Law number 26 Of 2000 has been filed for judicial review to the Constitutional Court (MK) and the case had been concluded. Based on the Decision of Constituional Court Number 18 / PUU-V / 2007, it was decided that the Elucidation of Article 43 paragraph (2) of Law number 26 Of 2000 on the Human Rights Court, regarding the word "alleged", is contradictory to the 1945 Constitution and declared null and void. Based on the Constitutional Court's decision, the authority of the DPR to propose the establishment of an ad hoc Human Rights Court to the President has not been annuled, but the proposed formation of the ad hoc Human Rights Court by the $D P R$ is clear, that based the Constitutional Court's decision, DPR need to pay attention to the results of Komnas HAM inquiry and the result of the Attorney General's investigation not on a self alleged by the $D P R$.

Although there has been a Constitutional Court decision number 18 / PUUV / 2007 which clarifies the mechanism of the formation of an ad hoc Human Rights Court initiated inquiry by Komnas HAM, followed by an investigation by the Attorney General and the results of the inquiry and investigation provided the basis for the DPR to propose the establishment of an ad hoc Human Rights Court to the President. However, until now there has been no follow-up for the establishment of an ad hoc Human Rights Court for past human rights violation cases. Because of the number of cases that inquiry conducted by Komnas HAM has been halted at the Attorney General. In other side, the previous DPR stated that the Trisakti case and Semanggi I and II were not cases of human rights violation so there was no need to established an Ad Hoc Human Rights Court has not yet been annulled or amended by $D P R$.

The issue of establishing an ad hoc Human Rights Court is not only related to the relationship between Komnas HAM, the Attorney General and the DPR but also the role of the President as the final decision maker for the formation of the Court through Presidential Decree. However, there is no stipulation on the timeframe for the President to issue a Presidential Decree to establish an ad hoc Human Rights Court upon the DPR's proposal. This led to the obscurity on when 
does the an ad hoc Human Rights Court established because it depends on the political will of the President. This happened to the DPR's proposal for the establishment of an ad hoc Human Rights Court on the cases of kidnapping and disappearance of people forcibly in 1997/1998 to President Susilo Bambang Yudhoyono (SBY) which was never realized until the end of his term. This conditions continues to the era of President Joko Widodo and there is also no sign that the DPR's proposal for the establishment of an ad hoc Human Rights Court for case of abduction and disappearance of persons forcibly in 1997/1998 will be realized.

\subsection{Weak Political Will of the Government}

The ineffectiveness of the settlement of human rights violations in Indonesia is also suspected due to the weak political will of the Government. The settlement of human rights violations has always been a political promise during the campaign of presidential candidates in every general election but the realization is far from expected. To see the political will of the President in the settlement of human rights violations in Indonesia during this reform era, it can be traced to any policy ever taken from President Habibie to President Joko Widodo. In the era of President BJ. Habibie, attempts to resolve past human rights violations that occurred during the New Order period were not expected to be effective, because after all President Habibie was an indispensable part of the New Order regime itself. Therefore it is impossible that the Habibie era to became a regime that can take a decisive action in solving human rights violations during the New Order era. Moreover, the government was in a transitional era so there was not much that could be done. However, in the era of President Habibie there was the establishment of Law number 39 Of 1999 on Human Rights and the issuance of Government Regulation in Lieu of Law (Perppu) number 1 Of 1999 on Human Rights Court which have been revoked because it was not approved by $D P R$.

In the 1999 general election, a democratic government was elected for the first time in an era of reform led by President Abdurrahman Wahid. As a figure who was known as a democracy and human rights activist, there was a huge hope for President Abdurrahman Wahid from the public that in the era of his leadership various cases of past human rights violations could be resolved. In the context of settling cases of human rights violations, the era of President Abdurrahman Wahid established Law Number 26 Of 2000 on the Human Rights Court and on 23 April 2001 issued a Presidential Decree on the establishment of an ad hoc Human Rights Court for East Timor and Tanjung Priok cases. This policy, of course, received appreciation from the public so that there were hopes for other cases to 
be immediately brought to the Human Rights Court. However, Abdurrahman Wahid's government did not last long because he was dismissed as President who was later replaced by Megawati who was previously Vice President.

In the era of President Megawati the hope for more effective settlement of human rights violations was increasing, especially Megawati was also a victim of human rights violations of the New Order era in an infamous case of July 27, 1996, an attacks on PDI office under the leadership of Megawati allegedly orchestrated by the military apparatus of President Suharto's regime. However, during President Megawati's administration there was no formation of an ad hoc Human Rights Tribunal to resolve past human rights violations but there was established a Truth and Reconciliation Commission under Law number 27 Of 2004. In the era of President Megawati there was also a controversial policy from the perspective of human rights, which conducted military operations in Aceh in the face of the separatist group of the Free Aceh Movement (Gerakan Aceh Merdeka, GAM). In this era, also occured the murder of human rights activist, Munir, who was poisoned on a flight to the Netherlands and allegedly involving State Intelligence.

After the end of President Megawati's administration era, the national leadership was continued by President SBY who was the first President elected by direct elections of the people. However, during the era of President SBY's leadership, in the effort to resolve past human rights violations, there was no significant development. In fact, in 2009 there was a proposal from the DPR to establish an ad hoc Human Rights Court related to the cases of abduction and disappearance of persons but until the end of the term, President SBY never issued a Presidential Decree on the establishment of an ad hoc Human Rights Court. For two periods of presidency but unfortunately in the era of SBY none of the cases of past human rights violations have been resolved.

The next development is in the era of President Joko Widodo who has been ruled for 3 Ofs with the promise of his campaign, namely "Nawacita", in the field of Human Rights will resolve cases of past human rights violations, but there is no action concretely. It seems that with the remaining of 2 Ofs of presidency plus the bustle of entering the political Of, it is feared that the effort to solve human rights violation in Joko Widodo Government is only a pledge.

Having seen the policies of the Presidents in the reform era in the effort to solve the past human rights violations, it appears that only President Abdurrahman Wahid has taken a firm policy by establishing an ad hoc Human Rights Court in order to solve the cases of Tanjung Priok and East Timor. While in the era of President Megawati, although there were no establishment of an ad hoc Human Rights Court, at least she had produced the KKR Law. While in the era of 
President Habibie, SBY and including Joko Widodo at this time there has been no concrete efforts in the settlement of past human rights violations.

The question arises why on a general level, a number of presidents in power in Indonesia during this reform era have not taken effective policies to resolve past human rights abuses? The failure of the completion of human rights violations in Indonesia during the reform era was due to the lack of political will from the ruling Government. There are several factors that cause the lack of political will of the President in power in this reform era to resolve various cases of past human rights violations, namely:

First, there is still a political force that enjoy power in the New Order era in the Government Cabinet and DPR in reform era so that the ruling government can not create a demarcation line with individuals or groups who were involved in human rights violations. Instead, what is happening is compromise and suspected negotiations of political interests between the ruling Government and those allegedly involved in human rights violations within the framework of share of power.

Second, there is a concern that if cases of human rights violations are investigated and reopened, it causes political instability that even threatens the power of the ruling Government. Third, the lack of pressure from civil society groups to continue to voice the resolution of cases of human rights violations so that the insistence on the settlement of past human rights violations by the ruling Government is not considered a priority because there is other issues that are considered more important.

\section{Solutions for the Settlement of Human Rights Violations in Indonesia}

After looking at a number of factors that cause the failure of the settlement of human rights violations in Indonesia, there should be solutions to overcome them. Therefore it is necessary to take immediate concrete steps to improve an effort to bring about justice for the victims and their families who suffer from the violation of human rights. The steps that should be done in resolving human rights violations in Indonesia are as follows:

\subsection{Amendment of Law on The Human Rights Court}

Amendment of laws and regulations relating to the protection and enforcement of human rights is to prioritize substantial improvements to Law Number 26 Of 2000 on the Human Rights Court. As for a number of weaknesses that must be corrected are:

First, the refinement of terms and the definition of what constitutes a gross violation of human rights and what kind of crimes is included in the category it. 
There should be an addition to the types of crimes that fall into the category of gross human rights violations that are in line with international standards, the Rome Statute.

Second, the improvement of mechanisms or procedures in handling cases of gross violations of human rights, namely improving the procedural law of the Human Rights Court and regulating institutional relations between Komnas HAM to conduct inquiry with the Attorney General as an investigator which should be synergized.

Third, in order to improvement of mechanisms or procedural law for the Human Rights Court, it should refer to the Rome Statute. The Rome Statute is supplemented by a special procedural law and an explanation of elements of crime which fall under ICC jurisdiction in two separate rules, the Rules of Procedure and Evidence as the procedural law, and the Element of Crimes as an explanation of its criminal elements. The two rules provide the same understanding of the substance as well as the procedures to judges and other law enforcement agencies in the context of the trials of perpetrators of crimes under the jurisdiction of the ICC (Halili, 2016, Op.Cit: 203).

Fourth, improvements in the ad hoc Human Rights Court establishment mechanism mainly to clarify the stage of its formation, namely no longer places the $D P R$ for the propose the formation of the ad hoc Human Rights Court and focuses on strengthening the authority of inquiry by Komnas HAM, such as it can force involuntary call to the parties requested to provide information.

Fifth, improvements to Law number 26 Of 2000 on Human Rights Courts is fundamental in nature and contain many improvements to the substance of the Law, it is better to not only change it partially but to establish a new Law on Human Rights Court with a better substance and adapted to the international development and practice as well as national needs.

\subsection{Arrangement Institutional Relations and Authority}

In an effort to improve the effectiveness of the settlement of human rights violations in Indonesia, there is no other way than to improve institutional relations within the framework of inquiry and investigation between Komnas $H A M$ and the Attorney General including the improvement of institutional relationship between institutions related to the establishment of the ad hoc Human Rights Court namely Komnas HAM, The Attorney General, the DPR and the President. This is important because the biggest obstacle in the settlement of human rights violations in Indonesia lies in the stagnation of cases in the Attorney General and the uncertainty of the stages in the formation of the ad hoc Human Rights Court. The steps that can be done in the effort of arrangement the authority 
and institutional relations in handling cases of gross human rights violations and the establishment of the ad hoc Human Rights Court are:

Firstly, the inquiry of cases of gross human rights violations shall be handle by Komnas HAM while the Attorney General acted as investigator and prosecutor. However, there should be an affirmation regarding the inquiry result that has been done by Komnas HAM which must be followed up with investigation and prosecution by the Attorney General to the Human Rights Court.

Second, for the results of inquiry conducted by Komnas HAM for past human rights violation cases, the inquiry result are submitted to the Attorney General for investigation and must also submitted directly to the President who in a certain period of time, must follow up by issuing a Presidential Decree in the formation of an ad hoc Human Rights Court. In this case, DPR has no longer involved in proposing the establishment of the ad hoc Human Rights Court because placing a political body such as the $D P R$ to engage in a case which is falls under the authority of law enforcement, is not appropriate.

Third, efforts to strengthen coordination within the context of inquiry by Komnas HAM on gross human rights violations should include personnel from the Attorney General's Office when it establishes KPP HAM. Likewise, in the investigation phase, the Attorney General should invites Komnas HAM as a partner to facilitate the process, especially to build effective communication in the settlement of human rights violations. With this model, there is a synergy, even from an early stage of a case, between Komnas HAM and the Attorney General in the inquiry and investigation.

\subsection{The Re-establishment of the Truth and Reconciliation Commission} (KKR)

In the context of settling past human rights violations other than through the ad hoc Human Rights Court it is also necessary to reshape the KKR. The reestablishment of the KKR is an alternative solution when law inforcement process through Human Rights Court has difficulty. In addition, the urgency to establish the $K K R$ in Indonesia is in order to reveal the truth which of course is still relevant, even more urgent, for the life of the Indonesian nation. In the spirit of nationality, a collective memory of the past must be built with a commitment to the protection of human rights. After three decades of excessive abuse of power, undemocratic life and violation to human rights, a systematic, official effort to uncover the truth is a prerequisite for releasing the nation from the shackles of the past (Working Group on the Disclosure of the Truth, 2008: 5-6) . 
In the re-establishment of the $K K R$ in Indonesia, the objectives of its formation must be formulated as a basis and in the direction to solve the problems of human rights violations that have occurred, namely :

1) to disclose the truth about human rights violations that occurred in relation to political factors and / or the response to authoritarian powers;

2) reporting findings on these human rights violations, including causal factors, previous background events, political and / or economic motivations, the practices of state institutions and non-state actors, as well as individual and institutional accountability, and the impact of the violation of human rights;

3) assisting the recovery of victims of human rights violations, in accordance with the universal standards relating to the rights of victims.

The establishment of the $K K R$ in Indonesia is inteded to reveal truth as a form of accountability process leading to a broader explanation so it is more than just an individual accountability or the discovery of facts. As expressed by Priscilla Hayner, the main commitment of the $K K R$ is not just a standard function of the Human Rights Commission, which is in charge of investigating human rights violations. The $K K R$ also a truth seeking that led to an accurate record of the country's past, as well as areas of potential conflict and sources of contention. Therefore, the work of the Commission is more than a fact finding that leads to the formulation of collective truths concerning various aspects of human rights violations. Consequently, the work of the $K K R$ leads to the collection of knowledge and truth that leads to recognition. The purpose of this kind of acknowledgment shows that "the state has acknowledged its wrongdoing, acknowledged its mistake, and made fundamental changes in the future" (Ifdhal Kasim and Eddie Riyadi Terre (ed)., 2003, Op.Cit: 345-346).

\subsection{The Strengthening of Political Commitment}

Various cases of past human rights violations are still not completed during the reform era due to a weak political will in human rights enforcement in Indonesia. Now the challenge and the burden to solve the various cases of human rights violations is placed on the shoulders of Joko Widodo Government. The issue is whether the challenges and burdens can be endured and resolved during the era of President Joko Widodo or he would just take the same old measure about the failure of the settlement of human rights violations.

It has been too long for the victims to wait for the certainty of the fate and the fulfillment of a sense of justice for their suffering. Various cases of human rights violations especially in the New Order era whose victims spread from Aceh 
to Papua, the suffering of victims of the 1965 incident, the obscurity of those who has been abducted in 1997-1998 which has not yet returned, Semanggi I and II, case riot of May 1998, Munir's murder case and many more victims of human rights violation and their families who are waiting for the responsibility of the state to complete. The country is owe it to the victims of human rights violation and their families to the reveal of truth about the events that befall them and to assure that the state is present to protect the rights, restore and preserve their dignity.

This is a challenge that must be answered and resolved by the Government of Joko Widodo as in his campaign, he promise to solve various cases of past human rights violations justly. To prove that Joko Widodo's Government is different from the previous Government, there needs to be a real policy to show commitment and political will that the current Government have and to show that the government are truly trustworthy to enforce human rights. The concrete steps that should be done by President Joko Widodo in the settlement of cases of human rights violations, namely:

First, it should immediately instructs the Attorney General to follow up on the recommendations of the inquiry result of Komnas HAM by conducting an investigation and bringing cases of human rights violations to the Human Rights Court.

Second, issue a Presidential Decree on the ad hoc Human Rights Court for cases of kidnapping and disappearances of person that proposed by $D P R$ since 2009. Third, the President together with the DPR should immediately amend the substance of Law number 26 Of 2000 on the Human Rights Court by enacting a new Human Rights Court Law in order to strengthen a more effective human rights enforcement system.

\section{CLOSING}

\section{Conclusion}

The failure of the settlement of human rights violations in Indonesia has been caused by several factors, namely:

1) the substantial weakness of legislation, especially Law number 26 Of 2000 on the Human Rights Court;

2) the issue of authority and institutional relationship between Komnas HAM and the Attorney General are not synergistic in handling gross violation of human right. As well as the uncertainty of the stages in the formation of the ad hoc Human Rights Court because the institutional relationships between related institutions such as Komnas HAM, the Attorney General, DPR and the President are also unclear so that each of the institution has different 
interpretations regarding the stages of the formation of the ad hoc Human Rights Court;

3) weak political will of the government in the era of reform in the effort to solve human rights violations.

\section{Suggestion}

Based on the factors that become obstacles in the settlement of human rights violations in Indonesia, it is necessary to take steps in an effort to solve them, namely:

1) improve the substantial weaknesses in Law Number 26 Of 2000 on the Human Rights Court by replacing it through the establishment of a new Law on Human Rights Court with the substance that strengthen an effective human rights enforcement system;

2) to organize institutional relations between Komnas HAM and the Attorney General in order to be synergistic in inquiry and investigating cases of human rights violations as well as related to clarify the stages or mechanisms to forming an ad hoc Human Rights Court;

3) re-establish the $K K R$ in order to reveal the truth about the human rights violations that occurred and oriented towards the recovery and fulfillment of victims' rights and their families;

4) The ruling government must have strong political will to resolve various cases of human rights violations with the support and pressure of civil society groups in demanding resolvement of various cases of human rights violations.

\section{BIBLIOGRAPHY}

\section{Books:}

Asplund, Knut D., dkk (ed), 2010, Hukum Hak Asasi Manusia (Human Rights Law), PUSHAM UII: Yogyakarta.

Kasim, Ifdhal dan Eddie Riyadi Terre (ed), 2003, Pencarian Keadilan di Masa Transisi (The Search for Justice in a Transitional Period), ELSAM: Jakarta.

\section{Journals:}

Abidin, Zainal, "Kerangka Penyelesaian Pelanggaran HAM Berat di Indonesia dan Negara-negara Lain”, Jurnal Dignitas, Volume VIII Number 1 Of 2012.

Halili, "Politik Penegakan Hak Asasi Manusia Pada Masa Transisi di Indonesia", Jurnal Civics, Volume 13 Number 2, December 2016.

Hastuti, Lina., "Pengadilan Hak Asasi Manusia Sebagai Upaya Pertama dan Terakhir Dalam Penyelesaian Pelanggaran Berat Hak Asasi Manusia di 
Tingkat Nasional", Jurnal Dinamika Hukum, Vol. 12 Number 3, September 2012.

Kasim, Ifdhal., “Komnas HAM dan Tantangannya Dewasa Ini”, Jurnal Dignitas, Volume VII Number 1 Of 2011.

\section{Papers:}

Soeprapto, Enny., 2011, "Meninjau Ulang UU Number 26 Tahun 2000 tentang Pengadilan Hak Asasi Manusia", Paper presented on Pelatihan HAM Lanjutan untuk Dosen Hukum dan HAM, held by Pusat Studi Hak Asasi Manusia Universitas Islam Indonesia (PUSHAM UII) in cooperation with Norwegian Centre for Human Rights (NHCR) University of Oslo, Yogyakarta, 8-10 June 2011.

\section{Websites:}

Kelompok Kerja Pengungkapan Kebenaran, 2008, "Sebuah Komisi Kebenaran untuk Indonesia: Sebuah Konsep Alternatif dari Masyarakat Sipil”, http:// www.kontras.org/data/kkr/naskah\%20kkr\%20nasional.pdf, Accessed on 10 February 2018. 